\title{
Investigation of Islamic Republic of Iran Foreign Policy (1997-2013)
}

\author{
Jalal Dehghani Firoozabadi ${ }^{1} \&$ Mojtaba Zare Ashkezari ${ }^{1}$ \\ Faculty of Law and Political Sciences, Allameh Tabataba'i Universiti, Tehran, Iran \\ Correspondence: Mojtaba Zare Ashkezari, Faculty of Law and Political Sciences, Allameh Tabataba'i Universiti, \\ Tehran, Iran. E-mail: dr.mojtabazare@gmail.com
}

\author{
Received: September 9, 2015 Accepted: October 23, 2015 Online Published: November 30, 2015 \\ doi:10.5539/ass.v11n28p274 URL: http://dx.doi.org/10.5539/ass.v11n28p274
}

\begin{abstract}
Foreign policy is very important because it deals with relations between governments and international system. So this study believes that a great part of foreign policy is developed under individual variables and inferences so the best choice to prove the argument would be realism new classic. It' due to in this theory there has been a special attention to individual factors and its effects on foreign policy. The main question is raised in this study would be how are the effects of Islamic Republic of Iran foreign policy approaches between 1997 till 2013. The authors believe during these years Islamic republic if Iran foreign policy has adopted two different approaches, an increasing tension approach and an aggressive invasive policy due to lack of an exact strategy in dealing with international system. At last the study results the individual factors and personality type of two previous presidents of Iran, Mr. Khatami and Mr. Ahmainejad has a great affect on Islamic republic position in international system. As we could observe at the first period we witnessed an increasing role in international system that ends with getting substantial benefits and in the second period we could obviously see the decrease of this position and isolation of the country in international system.
\end{abstract}

Keywords: Islamic republic of Iran foreign policy, international system, national interests, new classic realism, individual variables, Islamic republic position

\section{Introduction}

Foreign policy in international relations arena is a link between government's internal activities and global environment. It means internal factors play an important role in giving weight to foreign policy formation along with structure of international system and its specifications. So foreign policy of each country gets formed from two great factors. The first factor is values, history and governmental structure. The second factor which is international can impose its own specifications and desires to governments and also can make restrictions for partners.

Governments in international environment are bound to constant principles due to social, political, economic and conscience conditions. Of course each of them adopts its own approach and direction to apply the fundamentals and rules. In fact governments who are successful in diplomacy follow these three fundamental principles: 1) constant principles in foreign policy; 2) Policy and strategy which are codified according to constant rules in different political geography; 3) Executive approaches which governments try to apply according to special attitudes.

Therefore countries which use these three principles in their foreign policy can impose the best impact on foreign policy and provide the best benefits in international system and relation with other countries. Regarding the issue that there is constant fundamentals in foreign policy of Islamic republic and all approaches associated with these rules are executed, Islamic republic cant effort to develop its political, economical and cultural influence in international system.

There are main reasons for lack of a stable policy and strategy in Islamic republic which is as follow:

a. Parties couldn't really establish and do proper activities since Islamic revolution.

b. In absence of actual political parties before 1997 election system was formed before an actual election procedure so there wasn't a desire for candidates to submit and explain electoral slogans.

c. After Khatami from 2005 candidates had no chance to win in the electoral so there was no program for foreign and domestic policy and governments used to deal with their own programs. 


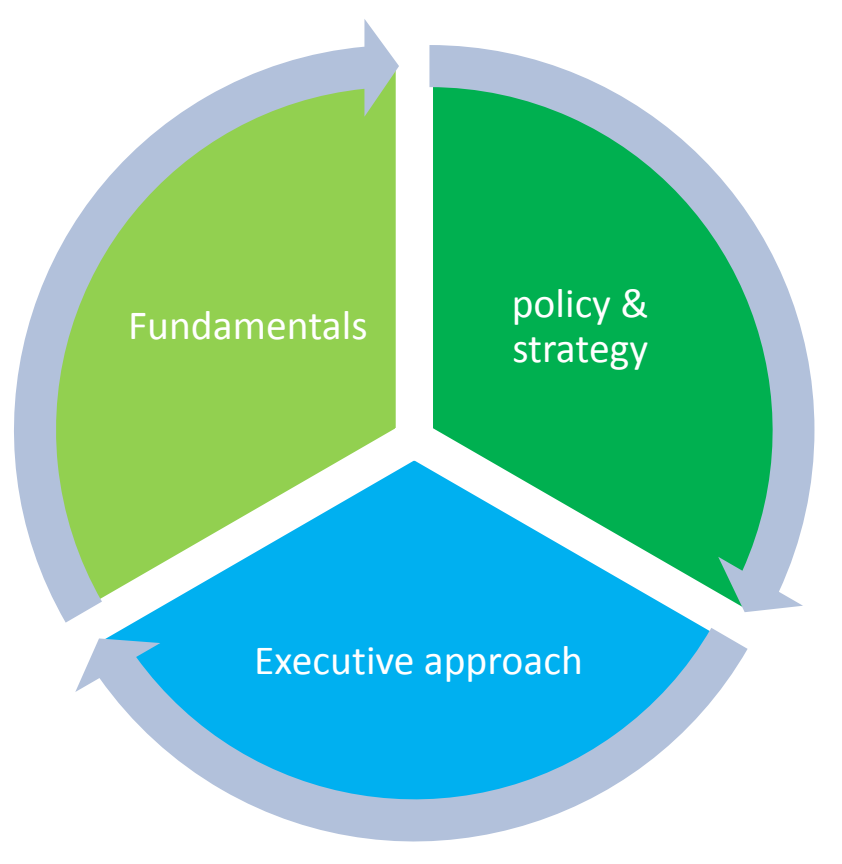

Along with issues listed above we can mention different realization of governments from revolution principles. In fact the difference is in exclusive and monopolistic view of governments for adoption and application of fundamental believes. This is against with new ways of ruling which in a great extent gets benefit of brainstorming procedures. In Islamic republic there are no such think tanks or if there is a small number they are used provided that they are according to governmental believes.

Regarding that in this study we pay attention to internal factors specifically individual and personality factors which forms the foreign policy and for this we need to investigate family, social position and political orientations of decision makers and effective people who affects foreign policy. Family provides an arena for a person to become a member of other organizations and it is the first organization which teaches social relations. We all know the role a child imagines for him/herself in the family and social context can affect on their imagery of the world and all decision makings including foreign policy. Therefore we tried to investigate the impact of individual variables in the extent of them in foreign policy in this study. There are differences in people for instance lack of experience or their degree of risk taking can be different because personality, values and thoughts of decision maker is a key factor in decision making procedure. Also moods and mental structures of leaders and decision makers have a great impact on policy and even have caused the policy to be substantially formed like individual nature.

So we witness each president as soon as is elected tries to adopt a fast and transient foreign policy according to their personality, requirements of time and country conditions without having specific program for foreign policy. For example in 1997 as soon as Mohammad Khatami won the elections, according to country's conditions and also regarding their west oriented approaches most of activities in diplomacy system directed to the west and Europe. At the same time with victory of Ahmadinejad in 2005 regarding bad attitudes towards western countries we witnessed a changing approach in foreign policy machine from Europe to less developed countries. So we can see because of a lack in specific strategy in foreign policy in different geography areas we couldn't get benefit from other countries in those areas. The reason as we mentioned before may be in methods of foreign policy principles understandings and actions of each government in Islamic republic and developing them by risk-taking and risk avert approaches and their derivations which we are going to deal with it later in this text.

In fact there are numerous factors in developing and forming of the foreign policy of a country and pay attention to these factors is so important to understand foreign policy in international relations. Foreign policy is measures that countries adopt to maximize benefits and minimize loss. On the other words, countries are going to get more benefit and avoid loss. They do proper actions to achieve these two goals. In one aspect we can say countries adopt risk-taking approaches or risk-avert approaches in order to get advantage or avoid loss in different position of foreign policy decision making. After 1997 elections, Khatami government took the control of the cabinet and a new era was raised in foreign policy of Islamic republic of Iran. Khatami tried to adopt a sufficient risk-avert 
policy to present a better image of Islamic republic and by making friendly relationship with those important countries who have more influence in international orders endeavored to decrease Iran's costs which was deeply in identity crisis and get more benefits by less costs. So, new variables entered in the foreign and domestic policies. In internal policy: cultural and political developments, realization of civil society, and in foreign policy: removing tensions, developing trusts and conversation between cultures were main agenda of the government in internal and foreign policy.

The country's policy switched to be risk-taking and maximize when Mahmood Ahmadnejad took the control of the government. In this period of diplomacy device along with criticism from passive and ineffective manner of previous government tried to reconstruct revolutionary concepts and become an active agent in international arena. In this period combat with global arrogance, negation of monopole system, conflict with western powers and criticism from international organizations in one side and advocate from Muslim and the poor, developing a global Islamic government, justice extension and removing discriminations around the world in other side were important issues in ninth and then in tenth cabinet. So, struggle with USA and other western countries and approach to Latin America countries and a look east policy were in main agenda of Ahmadinejad government. Therefore we witnessed a contrast and aggressive approach in international system.

\section{Psychological Effects}

Decision making is combined with decision maker's psychological specifications in such a way that we couldn't study one in absence of the other. Some factors and elements such as mood, intelligence, energy, insight and attitude, and emotions have a great role in decisions. Therefore from the perspective of psychology in studying the process of decision making one must considers all specifications of the decision maker. It means in addition to individual's position as an important factor for decision making, their personality and element which combines the personality must be taken into account.

But the science of politic psychology in Iran has been mostly subjective and theoretical. This is due to wrong mentality and concepts about psychology in government and non government elites. There are little studies which are dealing with political psychology of leaders and government officials (Kaarbo, 1997). Therefore in this study we deal with family conditions, social position and political approaches of two authorities who were decision makers and used to have influence on foreign policy because family and context which they are grown up in leads to behavior and thoughts. Although the foreign policy of Islamic republic of Iran follows exact rules but such fundamental rules could be changed practically when presidents with different personalities who take controls would have their own concepts, imagines and decision making specifications. In the following we will present a brief report about familial and social context of two previous presidents to somewhat identify the reason of the difference between their concepts about revolution and foreign policy.

\subsection{Seyed Mohammad Khatami}

Sayed Mohammad Khatami, son of late ayatollah sayed roohollah Khatami was born in 1943 in Ardakan, Yazd province. His father was one of well-known clergymen of that town. He established science school of Ardakan and was Imam in Friday prayer ceremony in Yazd once. Sayed Mohammad Khatami was studying in clerical school called Hozeh while he got his high school diploma in Qom. During these years he participated in political battles in 1962 and 1963. After that he interred in a philosophy course in the University of Isfahan. Along with studying in the university he continued studying in hozeh. He was accepted in a master's course in educative sciences in University of Tehran and returned Qom after he was graduated from the university. He passed some jurisprudence and basic courses in some clerical professors' classes such as Morteza Haeri Yazdi, Vahid Khorasani, Sayed Mousa Bashiri Zanjani, Shahid Motahari and Javadi Amoli. Also his responsibilities after victory of the Islamic revolution has been mostly in cultural and social issues such as president of Islamic center of Hamburg, ministry of culture in Mirhosein Mousavi cabinet, ministry of culture in Hashemi Rafsanjany cabinet, president advisor and manager of Iran national library (biography of Sayed Mohammad Khatami, 1385).

In terms of thoughts and political approaches Sayed Mohammad Khatami could be classified in modern left side party which is a new born current in Iran's political and social arena. Modern left is against with extremism, bureaucracy, violence and suppression (Taj zadeh, 2001). Modern left believes in decreasing tensions and variety in developing relations with other countries in foreign policy fields. The social position of this current must be seen in middle class, students, and some part of spirituals and open minded people (Zarifinia, 1999). Along with this approach, Khatami believes in critics and accepting critics and pays attention to two kinds of critic; criticism from traditions which are located instead of religion, and criticism of the west, not negation (Fairbank, 1997). Accordingly he introduced civilizations talk theory which was presented against clash of civilizations order to provide a proper floor to solve the foreign problems and also achieve the most important goal of country's 
foreign policy which was removing tensions which would leads to an increase in relationship between Iran and international system.

\subsection{Mahmood Ahmadinejad}

Mahmood Saboorchian, son of Ahmad Saboorchian was born in 1956 in Aradan from Garmsar county, Semnan province. His father was blacksmith and also teaching holey Qoran. Saboorchian family immigrated to Tehran in 1957 and changed their family name to Ahmadinejad. He passed his high school in Sadi and Daneshmant schools and accepted in university entrance exam with a score 132 and started studying in Elmosanat University in road engineering. He also was accepted in a master's course in the same university and become a faculty member of that university in 1989.

Ahmadinejad was one of the founders of Daftar Tahkim Vahdat, but some of its leader's denial such assertions. During the war he participated in different parts of the front as a volunteer mobilization soldier. After that he entered the Sepah. Also among his responsibilities we can mention to government of Maku, consultant of Kurdestan governer, cultural advisor of minister of culture and high education in year 1993, governor of Ardebil, faculty member of Elmosanat University, and mayor of Tehran (miga.ir). In the field of foreign policy in Ahmadinejad period we can mention to some specifications like aggressive and radical behaviors against western governments specifically in relationship with the US and also interactive with non western governments and active public diplomacy about nations.

Regarding approach and direction, Ahmadinejad belongs to right side or so-called fundamentalism. This movement established in front of religion open minded orients which were willing to change current religious structures such as spiritual system, accordance of spirituality with new values like democracy and human rights. This right side movement has been willing to keep current situation and was against with changes in traditional structures and believes. The term fundamentalism is also applied by them to describe their intellectual courses. Fundamentals criticize religious intellectuals to be negligence and west oriented (fa.wikipedia). It's crucial to say in second period of Ahmadinejad's presidency he surpassed initial goals of the Islamic revolution which were supported by fundamentals. He applied a new concept of fundamentalism to be a benchmark for such idea. His established group called "Rayeheye Khosh" introduced a new school which was based on his new idea.

\section{Foreign Policy of Iran during Khatami's Presidency}

At the same time with victory of Sayed Mohammad Khatami in second Khordad of 1997 it was created a substantial rotation in Islamic republic policies in internal level and international level. In this period Islamic republic of Iran according to its believed fundamental rules was looking for establishing relationship with foreign world, active and powerful presence in international arena and broadly speaking was against isolationism. Consequently it began a new round of relations and Iran's role in local and international level and with a belief to pluralism, interactive dependency, and cooperation with local and international organizations tried to have a powerful attendance in international arena. Along with such approach, so the Islamic republic of Iran's diplomatic device put tension removal policy on the agenda. Détente policy in this period was based on establishing a democratic system in the country and asking for peace and security from the world on the base of justice and stressing on the principle of equality and removing the force in international relationships, accepting and institutionalizing international law and regulations, paying attention to international and local organizations, accepting variety and plurality in communities and increasing the level of tolerance. Khatami's government tried to seriously observe and keep détente in foreign policy towards the international arena.

In addition he offered an active and creative approach about détente policy by means of introducing civilizations talk and enriching the détente policy by a theoretical and practical support. In fact accepting international system norms and following policies such as détente and civilizations talk from Khatami government were clues for a risk avert approach. This approach is called as a standard norm of rational choice which means it tries to avoid struggling and developing misunderstandings and tension with international system and it follows medium interests. This approach believes risk averting in alternatives would brought certain achievements and he, based on such point of view, determined his foreign policy a risk avert one. Khatami used to have a realistic view to the popularity of Islamic republic, its potentials, facilities, capabilities, and possibilities in countering with international system. He truly knew the consequences of opposition policies with the west. Khatami knew the great set which was under his leading is substantially affected by his adopted policies in international system so such policies would affect Iranians' life directly and somehow irreparable. Such reasons were so persuasive to waive revolutionary goals which were optimistically alluring and take a risk avert policy to bring out Iran from political and economical isolation which was developed due to embargo. Following risk avert policy by Khatami in this period of Islamic republic of Iran's policy through creative talks, positive publicity of media, efforts for 
trust building, and developing relation with west world cause to draw a new feature of Islamic republic in international system and it was a good help to absorb economic and political interests for Iran.

But the significant point is that Khatami's foreign policy must be as a part of foreign policy of Islamic republic of Iran because in determining, decoding and executing such foreign policies there have been other governmental and nongovernmental beneficiaries which were out of the field of supervising of Khatami's government.

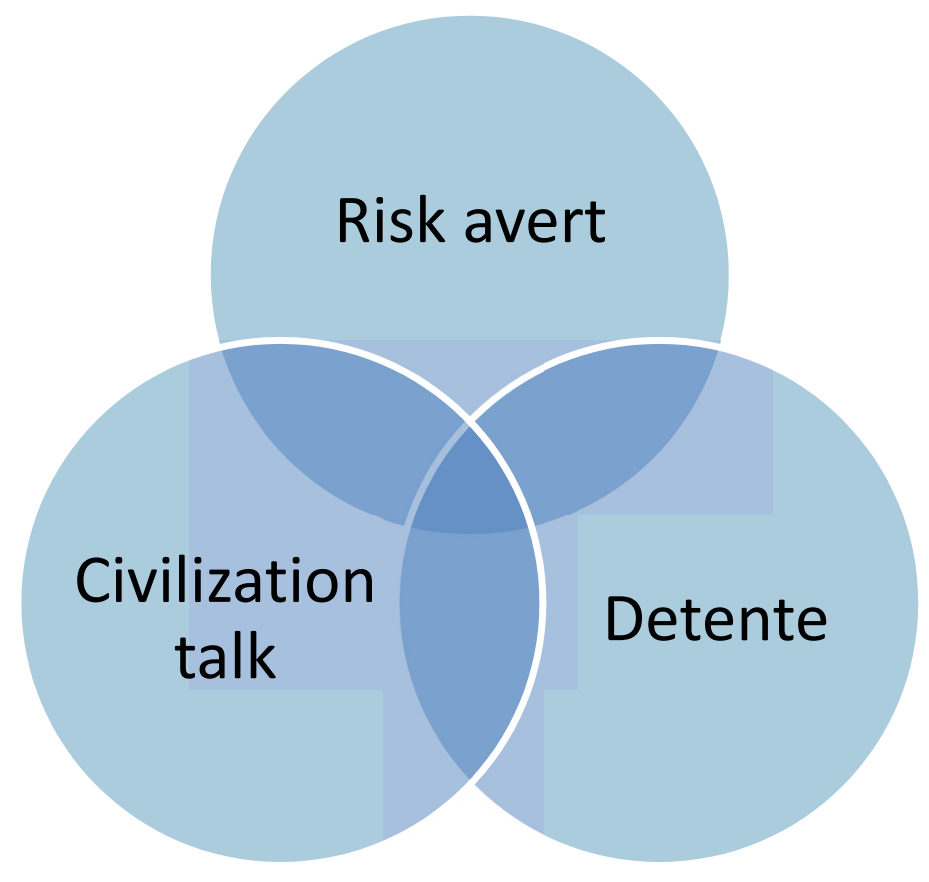

\subsection{The Concept and Nature of Détente}

Detente policy tries to maintain a peaceful balance between west and east relations on one side and relationship between main agents of international system and the third world countries on the other side by means of identifying current situation and accepting a need for a new order. Détente as a principle in international relations is always in access by means of peaceful ways and mental restructuring and by activating diplomacy through mutual talks and multilateral. It recognizes historical realities and focuses on identifying humanity values priorities. According to this point of view, cooperation for defending detente is actually a key term to describe the change in opposition relations between two or more agents and movement toward normalizing the relationship. But such normalization doesn't solely mean that all disagreements are removed, but it means that détente is just a way which shows relations of nations. According to this, the mentioned practice isn't a final solution for removing crisis but tries to provide a proper situation for countries to consolidate their relations through conversations and developing mutual understanding and based on peaceful coexistence principle. Therefore, political détente is a disciplinary and effective factor for continence and futurism. Détente needs rationality, wisdom, and transparency to find mutual fields of cooperation. It can, therefore, be a background for talks, friendship, patience, trust, and understanding on one side and develop peaceful counteractions in mutual cooperation.

The significant point is détente isn't limited to political and security dimensions but is a device for broad economical and cultural relationships. That means the key of mystery of détente is in economical, political, and social relations. Broadly speaking, in the framework of international relations détente is a reason for reducing disagreements and conflicts which may occur between two or more countries in international level. On the other word, the term détente is implies a trend which decreases or removes the tension which has been already existed. This is an introduction to establishing good and new relations (Mourgenta, 1995).

According to the meaning of the term détente, such a policy is able to not only be a responsible for values but also supply national interests in different cultural, economical, and social levels. The detente policy goes toward convergence and comprehensive cooperation by taking some distance from security and ideology priorities and consequently provides more opportunities for convergence and mutual cooperation. Such a policy calls all 
communities to move from violence and enmity to tolerating each other and cooperation and mutual trust and persuades countries to participate in mutual and multilateral relations and effective attendance in local and international organizations along with observance of tolerance principles in international relations. According to explained meaning we can sum up pillars of détente on the following three fundamental basics:

\section{a. Principle of conversation}

The meaning of talk or dialogue is mental and verbal interactions with some speakers about a subject or subjects to achieve a specific goal. The logic of the conversation is based on this reality that there is somebody else who is important. According to the meaning they have independent rights and it is likely for them to be right. From the beginning of the history dialogue has been the best way to remove hostilities among nations and families. But such conversation mostly contains broad spectrums and hasn't had a tangible effect to be presented in international system.

\section{b. Building trust principle}

Trust building practices firstly designed to avoid bad events in schism manners in the field of incompatible relations. Trust building practices act as creators of trust and the most important is that they provide conditions which are crucial for affecting changes on current situation. These practices have two specific faces. On one side they guarantee accepting the trust and on the other side they transfer the trust. So they are bound to trust as well as risk.

\section{c. Cooperation principle}

The main basic cooperation is satisfied in relations between countries. In the world of counteractive dependences, governments need mutual understanding and cooperation to achieve their mutual aims and satisfy desires. Forgetting commitments and using violent ways and nonconformity to good neighborliness is against cooperation principle.

So, cooperation develops along with commitments and fulfilling obligations. For the meaning of cooperation thinkers have presented different theories (Dibaji, 1390).

\subsection{Détente; Axis Khatami’s Foreign Policy}

Elelting Sayed Mohammad Khatami in second Khordad of 1376 became an important turning point in, both in internal policies and in foreign policies of Islamic republic according to internal and external observers. Khatami drew his foreign policy landscape on the following three principles: Détente, developing interactions, and civilization in the light of civilization talk theory. According to this base he asserted in his attestation ceremony: "The government of Islamic republic of Iran would avoid any convulsive behavior and activities". Therefore, although détente policy followed limitedly after the war between Iran and Iraq in the period of presidency of Hashemi Rafsanjani but such policy was presented as a basic principle in foreign policy in presidency period of Mr. Khatami broadly and comprehensively.

Mr. Khatami with a correct understanding of country's problems and economic needs, changes in international issues, and unsecured economical environment realistically recognized the détente as basic principle in foreign policy of Islamic republic to repair feature and prestige of the government and active attendance in international arena. The new government of Islamic republic of Iran and even other high ranked officials were well aware that just an active and logical detente foreign policy could bring the opportunity for using investments and developed technology to satisfy internal economical needs (Rashidi, 2008).

Accordingly, Kamal Kharrazi while meeting foreign ambassadors in Tehran described foreign policies of Islamic republic of Iran in international arena and focused on reducing convulsion in international relations, interactive economical dependency, global orientation, developing the role of international organizations, substantial increasing in the number of nongovernmental organizations, and necessity of partnership of all countries for solving international difficulties. He also declared Islamic Iran considers conversation as a principle and believes it is necessary for modern world (Tavazoni, 2002). Therefore, declaring the policy of detente made to the face of Iran repaired and improved.

But the significant point is the détente policy didn't mean that they leave off from revolution's principles and aims but such a policy was focused on three principles, according to the great leader of Iran, esteem, wisdom, and interest. So, Mr. Khatami declared: “I choose détente in foreign policy, but this doesn't mean we would leave our principles and we can defy the principles and removes other's abuse" (Lali M., What Khatami says talks about). Mr. Khatami while describing détente policy in supply, empowering, development, and establishing security and interests of Iran focused on this issue that: "Détente policy doesn't mean neglet about threads but it 
means understanding of enemy's borders and an effort to reinforce friendships and mutual features and awareness of threads". On the other hand, the détente policy calls all communities to avoid hostility and enmity and asks for mutual cooperation and would encourage countries participate in local and international activities while focusing on political, economical, and cultural plurality and observing principles in international relations.

Accordingly, Mr. Khatami in a meeting with resident ambassadors in February 10, 1998 said: "Our revolution wants peace and détente and developing relationship with all countries according to mutual respect and interests. Therefore the principle of détente is a serious principle for us and our diplomacy system would be more active according to that" (Lali M. , What Khatami says talks about). He believed we not only need to avoid making enemies but also add friends because modern world is a place for friendships and coordination. The foreign policy of Islamic republic of Iran in the period of presidency of Khatami, has concentrated on pursuing national goals and interests and removing tensions in relation with other countries and recognizing mutual and parallel interests which is supplies along with coexistence and cooperation with the others. In this period, the principle of peaceful coexistence in foreign policy contains significant and crucial concepts which are considered in the following: admitting to national interests and the role of Islamic republic of Iran in local and international affairs next to other local and international agents, negation of any kind of submissiveness and dominance, settling the conflicts between countries in a peaceful way and without using force and war and hostility, necessity for correction of power structure in international level based on justice and equality, active and effective presence of Islamic republic of Iran in settling local and global conflicts (Tajik, 2003).

In fact the peaceful existence policy of Khatami a framework in which it can be followed the resolution for global problems through peaceful interactive and talks in internal and international levels. But the important and significant point in Khatami's détente policy is the dialogue "political-cultural pragmatism". In fact, détente along with attention to political and historical realities and respect to human values is also a link for different nations. Totally, the détente diplomacy emphases on accepting variety and pluralism and increasing tolerance, and comprehensive, balanced, and sustained development. In this respect, détente policy of Khatami with a focus on conversation (political-cultural pragmatism) is different with détente policies in previous periods, especially with the one in Hashemi's period which used to focus on "economical pragmatism". We can express following axis from foreign policy as dialogue "political-cultural pragmatism" against "economical pragmatism":

Pursuing active local policy and effort to establish stability in the region, developing relationships with European countries, active participation in international organizations, rebuilding diplomatic relations with various countries, defend from country's values and identity, effort for increasing international understanding, endeavor for establishing peace along with justice and democracy and morality around the globe, reinforcement the culture of conversation, conference, and cooperation in the field of culture and civilization talk theory, playing an active and reform role in reinforcement of the Islamic conference organization and non-aligned movement and south-south cooperation (Tajik, 2003).

Broadly speaking, Islamic republic if Iran's foreign policy in Khatami period tried to go forward comprehensive convergence and cooperation in international system level along with détente, making some distance from security and ideological priorities and of course in the line of national and religious principles and values in order to provide a support for civilization talk and governmental multilateral convergence.

\section{The Foreign Policy of Iran during Ahmadinejad's Presidency}

The foreign policy of Islamic republic of Iran is unique in international system due to special personal and conscience specifications of its politicians and decision makers and dominant principles in constitutional law. Such specifications, specially, revealed more by rising Ahmadinejad in spring 2005. Specifically regarding this issue that fundamental government of Ahmadinejad was established after eight years of a peaceful democratic government. Although the fundamentalism conversation was declared from the first days of establishing Islamic republic as official policy of the government, but the Ahmadinejad's fundamentalism policy seems to be substantially different with the one before him. Adopting policies such as attachment to the east, developing cooperation with Islamic countries, increasing influence to African and Latin American countries, widespread promotion from Islamic movements such as Hamas and Hezbollah, opposition to dominant discipline in international system, and to challenging dominant powers were the most important policies which had applied by fundamental justice-based government of Mahmood Ahmadinejad.

Ahmadinejad believed that applying risk avert approach by Khatami's government not only had no benefits for the system but also has caused retreating from revolution principles to mention one, exporting the revolution, and appeasement in nuclear program. According to his idea such reason was enough for government policies to be aggressive and counteractive. He used risk-taking maximize-making approach instead of a risk-avert one. 
Such an approach which is less interested by countries in international system is called definite impact. It means as risk-averting in decisions has definite achievements, risk-taking has also definite loss. Ahmadinejad tries to divide the world to two domineering and power struggle camps by means of a risk-taking policy and introduce Islamic republic of Iran as the main advocator of Muslims and of course all weak people of the world to be in the list of powerful countries and to challenge international system.

Following such policies was confirmed with some principles rather than realities in international system, so international system couldn't affect in Islamic republic foreign policy.

\subsection{The Concept and Meaning of Fundamentalism}

The fundamental dialogue is described in Shia Islamic ideology just like other Islamism sub-dialogues. According to Shia political theory land and national government has no legal originality because in Islam such geographic borders which are used nowadays to divide Muslims into countries and nations has no originality. Also national government is required to nation and nationality which has no early validity and originality in Islam. The valid and legal political society in Islam is nation. Islam nation means a group of Muslims who make a united society by mutual religion and faith which is replace by nation. In this goal-oriented society Muslims have gathered based on a mutual goal and aim and all of them are seeking to supply and realize that sacred goal. Islamic government is also bound to make background and facilities for Islamic nation citizen to access such goals and aims. So, against with national governments which are based on nationalism ideology, Islamic government is based on Shia-Islamic ideology. Islamic government is a kind of government which considers verdict, legislation, and executing of the affaires according to Shia-Islamic standards and sentences as its own duty and legal task and Islamic government executives and leaders who are aware of Islamic principles, basics, and laws also act according to the holly religious framework (Dehghani, 2007).

I the Islamic republic fundamental dialogue an Islamic government which is arising from Islamic revolution and identified in Iran lands must consider both interests and goals of Iranians and interests and aims of Islamic revolution in foreign policy. Of course, this means foreign policy of Islamic republic of Iran contains two categories which are national and transnational goals and aims. These two goals have no inherent conflict and contrast with each other but may have some disturbance in act. On the other word, national and Islamic interests are along with each other not parallel. In fundamental dialogue, however, this is Islamic dominant values that identify national implications, interests, and goals. Therefore, Islamic Iran in the current international situation is as Islamic home which is obliged to protect existence, territorial integrity, independency and sovereignty, security, welfare and its development according to Islamic standards and revolution principles. Such goals and interests are introduction obligatory, and necessary for recognizing Islamic interests and Islamic revolution long term goals such as formation of Islamic world society, securing human happiness, defense from Muslims, promoting the weak, and removing world domination.

Accordingly, in addition to short-term vital security and economical interests we should seek the goals associated with global and ideological system in foreign policy. The interests focused on Islamic world order means establishing and maintaining an international Islamic system and order which in Islamic republic feels secure and able to do political, economical, and cultural activities in a peaceful way. Islamic republic ideological interests are protecting and developing a set of Islamic-revolutionary values which people have in common and believe that has a comprehensive universal accuracy and utility (Dehghani, 2007). In fact, the factor has mitigated foreign policy and has reinforced Islamic identity is the meaning of justice in Islamic republic system.

\subsection{Justice Dialogue}

Justice dialogue is consolidated around great meaning of justice. It is a set of sentences and theorems related to logical concepts, categories, classifications, and deductions which give a meaning of outer world to Islamic republic of Iran. This foreign policy dialogue gives a meaning to outer world, and Islamic republic positions and interactions with other actors in international system. The justice dialogue explains why Islamic republic of Iran in its foreign policy considers some role, interests, procedures, and behaviors possible and legal and some others impossible and illegal. This dialogue contains six main rile which are as follow: 1) Positive peace seeking; 2) Anti-oppression; 3) Anti-arrogance; 4) Revision quest and deconstructing; 5) Independence seeking; 6) Defense of the weak.

\subsection{Justice-Based Fundamentalism}

Fundamentalism means return to the principles and goals of the Islamic revolution in international arena. Idealism has specific indicators which forms Islamic republic foreign policy. Honor and Islamic esteem has a special priority and importance in fundamental foreign policy (Dehghani, 2007). Therefore Mahmood 
Ahmadinejad as the president of Islamic republic insisted in the point that the goal of internal and foreign policy would be resuscitation of early goals, values, and principles of the revolution and accordingly Ahmadinejad government announces in its first annual report: Fading out the evolution believes and original slogans in verbal and practical by executives in recent years had caused Islamic republic of Iran to be depressed and such problem has affected Muslim people and other deprived nations around the world. The esteem approach of the government in foreign arena through Islamic republic goals in Islam world caused Imam Khomeini's courses to be presented as realizable standards to bring Islamic nations out of arrogance dominance (spk-gov.ir/Repnts). Also current foreign affairs minister, Manoochehr Motaki, stipulates new directions of the government is conform to Islamic revolution and values of Islamic revolution of Iran, so the different fundamental approach towards international system, foreign policy, and specially relationship with the west is completely according to Islamic dialogue and Imam Khomeini's thoughts (Motaki, 2006).

Islamic revolution of Iran in the fundamentalism dialogue isn't just a national and limited revolution even it has a transnational and trans-boundary identity and nature. Hence, Ahamdinejad not only considers human's security, felicity, and excellence in internal society as a responsibility for governments but also enumerates the excellence of human society one of the most important responsibilities and prophecies of foreign policy (Dehghani firoozabadi, 1998). So, against two previous decades Ahmadinejad's foreign policy has been active and counteractive. Such an invasion and counteraction is very apparent and tangible, specifically about relationship with Europe and the US about nuclear file and Palestine problem. So, counteraction between Iran and the west, specifically The US reached to a pick of a period after Iran-Iraq war. But, without a doubt the most significant face of Iran active policy was revolutionary stand of Ahmadinejad about Israel and removing it from the world map (Dehghani Firoozabadi, 1999).

Intellectual and diplomatic supporting from Islamic movements and groups in this period is another device for introducing practical schema of a just Islamic government because defense of Muslims, the weak, and oppressed is one of the dimensions of justice seeking in foreign policy of a righteous Islamic government. Protecting Islamic movements is based on this assumption that Muslims have mutual benefits and interests which Islamic government is responsible for them. So, during 33 days Hibollah war against Israel Islamic republic of Iran firmly and enthusiastically supported Hizbollah clearly because Iran according to national role of "anti-Zionism agent" and "justice government" in framework of the identity of the justice government is bound and obliged to protect and support this Islamic movement. Also Islamic republic during invasion to Ghazah in 22 days war declared unsparing support of Islamic movement of Palestine because considered that war as a sample of an unfair war against defenseless people of Ghazah (Dehghani Firoozabadi, 1999).

Without a doubt the most important tool for Ahmadinejad government to produce a benchmark for an outstanding Islamic society has been a public diplomacy. Public diplomacy as a foreign policy tool is a process which the government of Islamic republic of Iran makes direct relations with other people and nations to develop Islamic revolution basics, goals, values, and dialogue in those communities. Islamic republic of Iran public diplomacy in this period has several specifications and basic rules: First, in public diplomacy, against with traditional and official diplomacy, the reference goals or audiences are publics in other communities, specifically unofficial groups of the society. Second feature of Iran public diplomacy has been transparency, flexibility, and its cooperative nature. Hence, Islamic republic of Iran has tried to make relationship clearly and directly with nations, nongovernmental agents, and world public opinion beyond closed, exclusive, traditional hierarchy models. This direct relationship is to propagate Islamic revolution values and goals. The third feature of Iran public diplomacy is about its goals. The main goal of this diplomacy is affecting on thoughts and minds of audiences in public field and forming public opinions for coordinating with Islamic revolution goals and Islamic republic of Iran policies. The forth feature and indicator in Islamic republic of Iran public diplomacy is its application practices in international arena (for this we can mention more than 112 interview of Ahmadinejad with international media and 31 time attendance in international news conferences). In the application of media tools such as press, radio and television all of these tools have a soft nature and are elements of software power (Dehghani firoozabadi, 1998).

\subsection{Justice}

The dominated dialogue of Islamic republic of Iran has changed greatly when Ahmadinejad came to power in a way that peaceful democratic dialogue has been replaced by justice-based fundamentalism. The framework and meaning finding in concepts of fundamentalism is focused around great word of "justice" in a way that the center of gravity in fundamentalism dialogue is justice and all other concepts get their meaning from it. Therefore, the base and axis of Islamic republic of Iran foreign policy in fundamentalism dialogue is justice seeking and developing justice in international arena. Seeking justice and developing it as indicators and 
benchmarks are two identity factor in foreign policy dialogue. In fundamentalism dialogue, in both theoretical and behavioral fields, the esteem principle has priority and preference to interests. The priority and preference of justice and esteem in foreign policy involves applying a benchmark for exporting Islamic revolution values and goals. The government of Ahmadinejad believed that Islamic republic of Iran has the identity of a "justice Islamic government" which its most important national role is "seeking justice" and "developing justice" (Dehghani firoozabadi, 1998). Seeking justice and developing it has conformity to quad identities; Iranian, revolutionary, Islamic, and non-aligned. It's because seeking justice during history has been a part of Iranian identity. Seeking justice requires to changing in current world situation for supplying proper Islamic order be a priority for foreign policy goals. Developing justice and establishing desired order in international system level has two sides. Establishing order and Islamic international justice system is done in two stages. First, destructing current situation, and second, promotion and consolidation of a desired Islamic order. Therefore, the aim is counteract with dominant system and dominators, and criticizing international organizations and institutions to make changes and transformation for establishing desired Islamic justice system. According to this, Ahmadinejad remids administers of diplomatic system that current mission of Islamic republic of Iran is correction and change in international relations structures to get nation's interests and drawing desired conditions (Dehghani firoozabadi, 1998).

\subsection{Positive Peacefulness}

The positive feature of fundamentalism dialogue and establishing desired order in international level is an effort for describing, explanation, and expressing Islamic justice which is an order and a system that will replaced after rebuilding and establishing current system. On the other word, after removing old order we need to rebuild and modernize a new order which is according to justice, equality, peace, and human security in such a way that a positive and direct relationship establishes between justice, and peace, and international security.

In principles presented by Ahmadinejad government the meaning of peace is beyond the concept of negative peace and actually means a lack in bare war and involves the concept of positive or maximum peace. The maximum peace also involves justice and convergence in human community base on destroying structural violence and institutionalized suppress in international level. Maximum peace puts war and violence in a broader context in social, economical, and political processes and doesn't limit it to just political trends. It's because of the fact that physical and political violence is expression of gaps and deep social and economical inequalities (Dehghani Firoozabadi, 1999).

Therefore, fundamental government has a maximum definition of positive peace. In such a view, a deep link establishes between peace, security and justice in such a way that this positive peace doesn't happen without recognizing justice, peace, and security. So justly peace, the most important basics and elements of desired global order and system, puts in the agenda of Islamic republic foreign policy (president.ir, 2006).

\subsection{Direction of Fundamental Government Foreign Policy}

Ahmadinejad foreign policy is based on negation of western hegemonic and unipolar policy and movement toward sustained multilateral oriented instead. Iran, in recent years, has shown that don't want to behave along according with global policies of the west specifically America and for this it has done broad efforts to develop its power based around the world. On the other word, after the rise of Ahmadinajad government Iran foreign policy changed entirely and moved along with involvedness. In fact, Islamic republic in recent years tries to determine dominant dialogue of its political relations and plays a game with them in its own framework (resalat-news, 2009). By adopting a moving foreign policy from president of Iran against international order, western governments and the United States started to make opposition with Islamic republic in order to isolate Iran through applying embargo in various fields. So, Ahmadinejad tried to achieve his goals by developing relations with other parts of the world and in this way we observe new patterns in Islamic republic of Iran foreign policy which can mention their most important as: Islamic republic of Iran foreign policy after occurrence of Islamic revolution changed greatly; Because foreign policy of each country follows internal policies we witnessed rising political elites in this period with different orientations compare to previous system. They got the administration positions so foreign policy of Iran changed basically and the policy of a look to the east and the third world became one of priorities in diplomatic system.

\section{Conclusion}

This study tries to readout Islamic republic of Iran foreign policy in two time period under command of two presidents with completely different and opposed character, studies the effect of individual role and their applied policies. The need for determining such an issue by new classic realism is clearly obvious. Because new classic realism is the best choice in existence theories in field of foreign policy to investigate Islamic republic of Iran 
foreign policy in these two completely different periods, both about attendance of Iran in international system and personality type of steersmen of such policies. Although there are various reasons for choosing this theory but we can mention a few as: In fact this theory not only emphasizes on various levels but also, more than any other theories, stresses on the role of decision makers and their understanding of the position and the world. Also according to this theory which believes in the role of financial power in prestige and position of the governments we can describe differences between Iran foreign policy in Khatami and Ahmadinejad.

Specifically, the foreign policy of Islamic republic during 1997-2013 divides into two periods. The first period between 1376 till 1384 contains détente policy and improving relations with west world and increasing Islamic republic position in international system. The second period between 2005 till 2013 the Islamic republic declares its foreign policy as an aggressive and counteractive. Such policies not only drew Iran to the isolation but also caused the position of the country to be decreased in international arena. In a brief explanation about these two periods we need to say with rising Khatami government détente policy was declared as the main axis of Iran foreign policy. The reformist government accelerated the trend of political development in the country and introducing concepts such as civilization talk and détente out of the country and tried to show a new political feature of Iran in world public opinion.

Khatami, by following détente policy, had a substantial effect in changing the world opinion about Iran. He tried to draw a new perspective for future of Iran and world community by following an optimistic view. Accordingly, the relationship with the west improved and consequently caused improving in economical and political benefits. The nuclear file problem under détente dialogue went toward interaction and trust (although it didn't have a result due to The US and Europe policies). Empowering and movement of diplomatic activities, starting good talks with America and Europe and returning European ambassadors, positive media advertisements, prohibited practices, trust making and introducing a cleared and positive feature of Iran foreign policies are among the most important results of détente policy.

But we need to consider Ahmadinejad fundamental foreign policy completely different from détente policy in Khatami government. Just the détente was accepted as official policy of Islamic republic of Iran in international community, Ahmadinejad replaced tension. To count some of factors of such a tension we can say: Ahmadinejad desires to introduce Islamic republic and conveying its revolutionary values to other nations, denial of Holocaust, a hope for removing Israel from the world, clear support of political and military groups such as Hamas and Hizbollah, invasion to embassy of Britain which was disapproved only by foreign minister. While the west especially Israel was willing to introducing Iran's new president as a negative character, he also reinforced such idea due to his self-centered personality. He believed he could really change current global dialogue and be successful in distributing power and wealth and changing world people opinions about Islamic republic of Iran and isolation of America and Israel. Pursuing such policy by Ahmadinejad fundamental government caused enmity against Islamic republic increases by means of some agreements were done by some government which were impressive in international system. Along with increasing the hostility against Islamic republic, several resolutions were approved by Security Council against Iran. Nuclear power agency accused Iran to effort for producing atomic weapon. The relationship with European and American countries decreased to its lowest level. The most unprecedented embargos applied against Iran in all dimensions.And finally, military threats against Iran became a regular routine.

Ahmadinejad introduced himself to the world community by the slogan of reviving Islamic and revolutionary principles and values while such a claim had no real support in foreign policy. Such a different approach had substantial results in internal and international dimensions. Ahmadinejad government by criticizing lacal and international organizations, institutions, and partitioning not only couldn't be able to use their potential abilities and facilities to increase Iran's interests but also caused all of their effort and power to concentrate against Iran's interest. On the other hand, his emphasis on the policy of a look towards the east was doing in a situation he didn't anything to solve the conflicts with the west.

In a general, the most significant point in comparison between Ahmadinejad and Khatami governments, as we mentioned in main hypothesis, would be as follow: the Islamic republic of Iran foreign policy during 1997 till 2013 because of lack of an exact and specified strategy have had two completely different approach, on one side détente, and on the other side an offensive and counteractive policy in encountering international community. So, it has resulted in increasing the position of Iran and finally its decrease in international system during 1997-2005 and 2005-2013. In fact, in reformist government they have tried to improve relations with all the countries around the globe and introduced a peaceful and civilized feature of Iran to international system, of course we couldn't claim all of these policies were done completely and without a deficiency, but in period of principle-based fundamentalism the previous polices were encountering clear and official opposition. Also 
applied policies such as opposition to great powers, claim for being a nuclear power, removing Israel, etc. caused Islamic republic of Iran to be considered as a dangerous country which is going to destroy international system, and many countries, except some poor countries in Africa and Latin America which have no international influence and aren't Iran's strategic influence depth, started to oppose with Islamic republic in many economic, political, and military levels. As a result, according to applied policies by these two presidents we can find direct relation between the impacts of the environment where a person is grown in and their formed personality, and their reactions to surrounded environment.

\section{References}

(2009). http://www.resalat-news.com1388.

Ahmadinejad, M. (2006). www.President.ir/Farsi/ahmadinejad/Cronicnews/1385/06/29/index-F.htm.

Dehghani firoozabadi, s. j. (1998). Lliberation foreign policy: critical theories and foreign policy of Islamic republic. Siasat kharej (2).

Dehghani Firoozabadi, S. j. (1999). The pattern for exporting revolution in ninth government foreign policy. (1).

Dehghani, s. J. (2007). Justice-based fundamentalism dialogue in Ahmadinejad government foreign policy. Danesh siasi

Dibaji, A. (1390). Building trust and political commitment. Strategy journal, (17).

Firoozabadi, D. (1390). Coalition requirements for peace. Foreign policy journal, (3).

Firoozabadi, D., \& Sayed Jalal, R. (1998). Ninth government foreign policy. Rahyaft siasi va beinolmelali, (13).

Gideon, R. (1998). Neoclassical Realism and Theories of Foreigen Policy. World Politics, 51(1).

http://www.spk_gov.ir/Repnts.asp?Itemid=22564.p.

Kaarbo, J. (1997). Prime Minister Leadership Styles in Foreige Policy Decision Making: A Framework for Research, 18(3).

Khatami, M. (2006). www.Khatami.ir,2006.

Kitchen, N. (2010). Systemic pressues and Domestic Ideas: A Neoclassical Realist Model of Grand Strategy Formation. Review of International Studies.

Lali, M. (1999). (What Khatami says talks about). Tehran: Akhlagh ava andisheye eslami.

Mojtahedzadeh, P. (2004). The position for justice morals in Iranians' national identity. Davood Mirmohammadi.

Motaki, M. (2006). Ninth government foreign policy: One year later. Tehran: center for middle east strategic research.

Mourgenta, H. c. (1995). Inter-Nations Policy. (H. moshirzadeh, Trans.) Tehran: Bureau of political and international studies.

Ninth government annual report. Secretariat for government information council.

Stephen, F. (1997). IRANS New Leadership. Retrieved from http://www.pbs.org.Retrieved 2/7/2005-.

Taj zadeh, S. M. (2001). Speech in Daftar Tahkim Vahdat camp. Tabriz.

Tajik, M. (2003). Foreign policy: Arena for lack of determination and plan.

Tavazoni, B. (2002). Timeline of Iran foreign policy. Tehran: Center for Islamic Revolution.

www.fa.wikipedia.org/wiki.

www.migna,ir/vdcceeqs.2bqoelaa2.html.

Zarifinia, H. (1999). Aautopsy of Iran political wings 1358-1387. Tehran: Azadi Andishe.

\section{Copyrights}

Copyright for this article is retained by the author(s), with first publication rights granted to the journal.

This is an open-access article distributed under the terms and conditions of the Creative Commons Attribution license (http://creativecommons.org/licenses/by/3.0/) 